Article

\title{
Durability Indicators for Sustainable Self-Consolidating High-Strength Concrete Incorporating Palm Oil Fuel Ash
}

\author{
Md. Abdus Salam ${ }^{1}$, Md. Safiuddin ${ }^{2,3, *}$ and Mohd. Zamin Jumaat ${ }^{4}$ \\ 1 Department of Civil Engineering, Dhaka University of Engineering and Technology, Gazipur-1700, \\ Bangladesh; masalam@duet.ac.bd \\ 2 Angelo Del Zotto School of Construction Management, George Brown College, 146 Kendal Avenue, Toronto, \\ ON M5T 2T9, Canada \\ 3 Department of Civil Engineering, Ryerson University, Toronto, ON M5B 2K3, Canada \\ 4 Department of Civil Engineering, University of Malaya, Kuala Lumpur 50603, Malaysia; zamin@um.edu.my \\ * Correspondence: msafiuddin@georgebrown.ca
}

Received: 18 May 2018; Accepted: 3 July 2018; Published: 6 July 2018

\begin{abstract}
This paper presents the durability indicators for sustainable self-consolidating high-strength concrete (SCHSC) including palm oil fuel ash (POFA) as a supplementary cementing material (SCM). SCHSC mixes were prepared by varying the water to binder (W/B) ratio and POFA content. The W/B ratio was varied in the range of 0.25 to 0.40 , and the POFA content differed in the range of $10-30 \%$ to produce the desired SCHSC mixes. The tests conducted on the freshly mixed SCHSCs to evaluate their filling ability, passing ability, and segregation resistance were slump flow, J-ring flow, and sieve segregation, respectively. To evaluate the durability of the hardened SCHSCs, the compressive strength, water absorption, and permeable porosity were examined along with the ultrasonic pulse velocity (UPV). The correlations between different hardened properties were derived to ascertain the durability indicators for sustainable SCHSCs. It was observed that most of the SCHSCs possessed excellent filling ability and passing ability with adequate segregation resistance. The test results also revealed that the compressive strength and UPV increased, whereas the water absorption and permeable porosity decreased with a lower W/B ratio and a higher amount of POFA (up to $20 \%$ weight content). Moreover, strong correlations were found between the different hardened properties of SCHSC. These correlations were used to determine the durability indicators for sustainable SCHSC with respect to compressive strength, permeable porosity, and water absorption. In accordance with the derived durability indicators, the sustainable SCHSC mixes produced in this study had the durability levels varying from "high" to "outstanding".
\end{abstract}

Keywords: durability; fresh properties; palm oil fuel ash; permeable porosity; self-consolidating concrete; ultrasonic pulse velocity; water absorption; water to binder (W/B) ratio

\section{Introduction}

Self-consolidating high-strength concrete (SCHSC) is a combination of high-strength and self-consolidating concretes. Generally, high-strength concrete (HSC) is densely reinforced. It is very difficult to vibrate and compact normal concrete into the congested reinforcement using the typical vibration technique. Self-consolidating concrete (SCC) has the capability to eliminate this problem by filling every corner of the formwork without any aid of vibration [1]. SCC is a special concrete that flows and compacts under gravity. If HSC is self-consolidating, the compaction of concrete in densely reinforced structural elements with high homogeneity would be an easy work. SCHSC fills the whole form completely without any defects. 
SCC was first considered in Japan in 1983, when concrete durability, constructability, and productivity became the major topics of interest in the 20th century. During that period, there was a shortage of skilled workers in Japan, which directly affected the quality of concrete [2]. The use of SCC reduces labor requirement and noise pollution by eliminating the need of either internal or external vibration. Also, the use of SCC results in a longer life to concrete form, improved surface finish, and a shortened construction period.

Okamura and Ozawa [3] advocated the development of SCC in 1986, and developed the first prototype in 1988 [4]. The maximum benefits from SCC can be achieved when it possesses excellent flowing ability (filling ability and passing ability) and adequate segregation resistance. These properties of SCC depend on the proper combination of limited coarse aggregate, a low water to binder (W/B) ratio, and high-range water reducer (HRWR) dosage [3]. In addition, the incorporation of suitable supplementary cementing materials (SCM) can help to improve the flowing ability and segregation resistance of SCC. Silica fume, ground granulated blast-furnace slag, fly ash, and rice husk ash are the successfully used SCM in SCC [3,5-7]. Similarly, palm oil fuel ash (POFA) can be used as an SCM to produce an SCC with excellent flowing ability and good segregation resistance [8]. Moreover, the use of POFA decreases the demand for cement in the construction industry, and thus reduces the cost of concrete production and lessens the environmental pollution caused by the $\mathrm{CO}_{2}$ emission from the cement factories [9]. These benefits imply that POFA could play a significant role in producing sustainable SCHSC.

POFA is a byproduct of the palm oil industry. It is considered a waste material in tropical countries such as Malaysia, Indonesia, and Thailand. The end products of the extraction process of oil from the fresh palm fruit, particularly husk and shell, are burnt in palm oil mills at the temperature of $800-1000{ }^{\circ} \mathrm{C}$ to produce steam, which is used in turbine engines for supplying electrical energy to the whole mill for milling operation and domestic or estate use [10,11]. The ash designated as POFA is obtained after the burning process. Usually, POFA is dumped in an open field near palm oil mills, thus creating environmental pollution and a health hazard [12,13]. To find a sustainable solution, several studies have been conducted to examine the feasibility of using POFA in various types of concrete. The research outcomes confirmed that finely ground POFA can be used successfully as an SCM for producing different types of concrete, including SCHSC [14-16]. However, limited studies have been carried out to investigate the durability properties of SCHSC incorporating POFA. Alsubari et al. [17] investigated certain durability properties such as drying shrinkage strain and initial surface absorption, as well as the compressive strength of SCHSC replacing $0 \%, 10 \%$, and $20 \%$ of cement by POFA. Ofuyatan et al. [18] studied the durability properties of SCC for acid resistance, sulfate attack, and saturated water absorption at the ages of 14 days, 28 days, 56 days, and 90 days using POFA at varying percentages of $0 \%, 5 \%, 10 \%, 15 \%, 20 \%, 25 \%$ and $30 \%$ by weight of cement. Ranjbar et al. [19] produced SCC by incorporating POFA at $10 \%, 15 \%$, and $20 \%$ by weight of Portland cement, and their compressive strength and durability potential were evaluated under normal, acid, and sulfate attack conditions. Nevertheless, none of the aforementioned studies provided any durability indicators for sustainable SCHSCs. The present study produced various sustainable SCHSC mixes with $0 \%$ to $30 \%$ POFA as a partial replacement of ordinary Portland cement (OPC) by weight. The fresh SCHSCs were tested for slump flow, J-ring flow, and sieve segregation. The hardened SCHSCs were tested for compressive strength, ultrasonic pulse velocity (UPV), water absorption, and permeable porosity. Moreover, the correlations between the various hardened properties were accomplished to determine the durability indicators for SCHSC with regard to compressive strength, permeable porosity, and water absorption, which were used to ascertain the different durability levels for sustainable SCHSC.

\section{Materials and Methods}

\subsection{Materials}

Coarse aggregate (CA), fine aggregate (FA), ordinary Portland cement (OPC), POFA, normal tap water (W), and a polycarboxylate-based high-range water reducer (HRWR) were used in this 
research. The CA was crushed granite stone with a maximum size of $20 \mathrm{~mm}$. The FA was mining sand with a maximum size of $4.75 \mathrm{~mm}$. CA and FA were tested to determine their specific gravity, bulk density, water absorption, moisture content, and gradation. The specific gravity, bulk density, water absorption, moisture content, and fineness modulus of CA was $2.62,1513 \mathrm{~kg} / \mathrm{m}^{3}, 0.55 \%$, $0.27 \%$, and 6.76 , respectively. The specific gravity, bulk density, water absorption, moisture content, and fineness modulus of FA was $2.69,1700 \mathrm{~kg} / \mathrm{m}^{3}, 1.32 \%, 0.31 \%$, and 2.88 , respectively. The particle size distributions of FA and CA are shown in Figure 1.

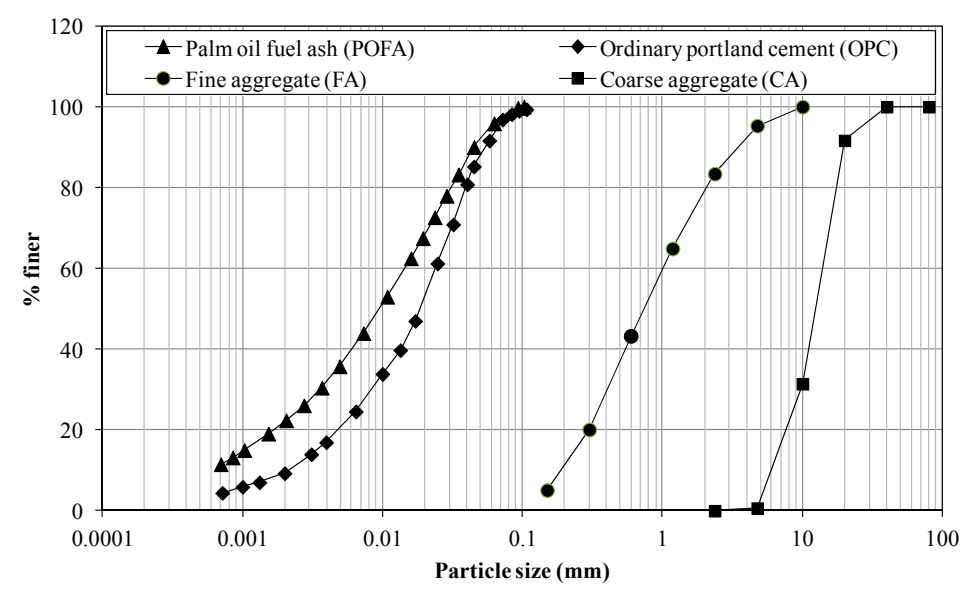

Figure 1. Particle size distribution of POFA, OPC, FA, and CA.

POFA and OPC were tested for their specific gravity, sieve fineness, specific surface area, and chemical composition. Both Blaine and BET test methods $[20,21]$ were used to determine the specific surface area of POFA and cement. The strength activity index of ground POFA was found as $105 \%$ at 28 days according to the procedure used for silica fume, as given in ASTM C 1240 [22]. The physical properties and chemical compositions of OPC and POFA are given in Tables 1 and 2, respectively. The particle size distributions of POFA and OPC are shown in Figure 1. HRWR was also tested for its solid content and specific gravity. The specific gravity and solid content of HRWR was 1.05 and $30 \%$, respectively.

Table 1. Physical properties of OPC and POFA.

\begin{tabular}{cc}
\hline Ordinary Portland Cement (OPC): & \\
\hline Specific gravity & 3.16 \\
Fraction passing through a $45-\mu \mathrm{m}$ sieve $(\mathrm{wt} . \%)$ & 91.5 \\
Specific surface area, Blaine $\left(\mathrm{m}^{2} / \mathrm{kg}\right)$ & 351 \\
Specific surface area, BET $\left(\mathrm{m}^{2} / \mathrm{kg}\right)$ & 3046 \\
\hline Palm oil fuel ash (POFA): \\
\hline Specific gravity & 2.48 \\
Fraction passing through a $45-\mu \mathrm{m} \mathrm{sieve}(\mathrm{wt} . \%)$ & 95 \\
Specific surface area, Blaine $\left(\mathrm{m}^{2} / \mathrm{kg}\right)$ & 775 \\
Specific surface area, BET $\left(\mathrm{m}^{2} / \mathrm{kg}\right)$ & 4103 \\
\hline
\end{tabular}

Table 2. Chemical compositions of OPC and POFA.

\begin{tabular}{ccc}
\hline \multirow{2}{*}{ Chemical Component(s) } & \multicolumn{2}{c}{ Quantity (wt.\%) } \\
\cline { 2 - 3 } & OPC & POFA \\
\hline $\mathrm{MgO}$ & 1.70 & 3.67 \\
$\mathrm{Al}_{2} \mathrm{O}_{3}$ & 3.44 & 3.18 \\
$\mathrm{SiO}_{2}$ & 15.20 & 62.27 \\
$\mathrm{P}_{2} \mathrm{O}_{5}$ & 0.40 & 3.64 \\
\hline
\end{tabular}


Table 2. Cont.

\begin{tabular}{ccc}
\hline \multirow{2}{*}{ Chemical Component(s) } & \multicolumn{2}{c}{ Quantity (wt.\%) } \\
\cline { 2 - 3 } & OPC & POFA \\
\hline $\mathrm{SO}_{3}$ & 3.91 & 0.36 \\
$\mathrm{~K}_{2} \mathrm{O}$ & 0.40 & 7.89 \\
$\mathrm{CaO}$ & 71.79 & 4.89 \\
$\mathrm{TiO}_{2}$ & 0.13 & 0.17 \\
$\mathrm{MnO}$ & 0.07 & 0.16 \\
$\mathrm{Fe}_{2} \mathrm{O}_{3}$ & 2.88 & 13.57 \\
$\mathrm{CuO}$ & - & 0.09 \\
$\mathrm{ZnO}$ & - & 0.03 \\
$\mathrm{Rb} 2 \mathrm{O}$ & - & 0.04 \\
$\mathrm{SrO}$ & 0.03 & - \\
$\mathrm{SiO}_{2}+\mathrm{Al}_{2} \mathrm{O}_{3}+\mathrm{Fe}_{2} \mathrm{O}_{3}$ & 21.52 & 79.02 \\
\hline
\end{tabular}

\subsection{Mix Proportions of Sustainable SCHSCs}

Sixteen sustainable SCHSC mixes were prepared using $0-30 \%$ ground POFA as a partial replacement of OPC by weight meeting the criteria of high-strength SCC. The W/B ratios of $0.25,0.30$, 0.35 , and 0.40 were selected to achieve high strength. The water content was approximated according to ACI 211.4R-08 [23], and the cement content was varied based on the selected W/B ratios.

The POFA content was selected based on the literature concerning the utilization of POFA in HSC. It was found in the literature that POFA can be used as an SCM with a content of up to $40 \%$ by weight of cement [15]. However, the optimum content is $20-30 \%$, because a POFA content higher than $30 \%$ may adversely affect the properties of concrete [24,25].

The fine aggregate to total aggregate $(\mathrm{TA}=\mathrm{FA}+\mathrm{CA})$ ratio (FA/TA ratio) used for all of the SCHSC mixes was 0.50 , which was obtained based on the maximum bulk density of aggregate blends. The HRWR dosage for a concrete batch was adjusted during mixing to ensure a slump flow in the range of $600-800 \mathrm{~mm}$.

SCHSC mixes were designated based on their $\mathrm{W} / \mathrm{B}$ ratio and POFA content. For example, C25P0 was used for an SCHSC mix that had a W/B ratio of 0.25 and a POFA content of $0 \%$. The designations and mix proportions of various SCHSC mixes are given in Table 3.

Table 3. Details of mix proportions for different sustainable SCHSC mixes.

\begin{tabular}{|c|c|c|c|c|c|c|c|c|}
\hline \multirow{2}{*}{ Concrete Mix } & \multirow{2}{*}{ W/B Ratio } & \multirow{2}{*}{$\begin{array}{c}\mathrm{CA} \\
\left(\mathrm{kg} / \mathrm{m}^{3}\right)\end{array}$} & \multirow{2}{*}{$\frac{F A}{\left(\mathrm{~kg} / \mathrm{m}^{3}\right)}$} & \multirow{2}{*}{$\frac{\text { OPC }}{\left(\mathrm{kg} / \mathrm{m}^{3}\right)}$} & \multicolumn{2}{|c|}{ POFA } & \multirow{2}{*}{$\begin{array}{l}\text { Water }^{\dagger} \\
\left(\mathrm{kg} / \mathrm{m}^{3}\right)\end{array}$} & \multirow{2}{*}{$\begin{array}{l}\text { HRWR } \\
(\% \text { B *) }\end{array}$} \\
\hline & & & & & $\left(\% B^{*}\right)$ & $\left(\mathrm{kg} / \mathrm{m}^{3}\right)$ & & \\
\hline C25P0 & 0.25 & 780.0 & 779.7 & 705.9 & 0 & 0 & 176.5 & 1.8 \\
\hline C25P10 & 0.25 & 772.0 & 771.4 & 635.3 & 10 & 70.6 & 176.5 & 1.8 \\
\hline C25P20 & 0.25 & 763.0 & 761.0 & 564.7 & 20 & 141.2 & 176.5 & 2 \\
\hline C25P30 & 0.25 & 754.0 & 752.1 & 494.1 & 30 & 211.8 & 176.5 & 2.1 \\
\hline С $30 \mathrm{P0}$ & 0.30 & 834.0 & 833.2 & 588.2 & 0 & 0 & 176.5 & 1.5 \\
\hline C30P10 & 0.30 & 827.0 & 825.6 & 529.4 & 10 & 58.8 & 176.5 & 1.575 \\
\hline С $30 \mathrm{P} 20$ & 0.30 & 819.0 & 817.1 & 470.6 & 20 & 117.6 & 176.5 & 1.8 \\
\hline C30P30 & 0.30 & 811.0 & 809.9 & 411.8 & 30 & 176.5 & 176.5 & 1.925 \\
\hline С $35 \mathrm{P0}$ & 0.35 & 872.0 & 871.4 & 504.2 & 0 & 0 & 176.5 & 1.25 \\
\hline C $35 \mathrm{P} 10$ & 0.35 & 867.0 & 865.3 & 453.8 & 10 & 50.4 & 176.5 & 1.2 \\
\hline C35P20 & 0.35 & 860.0 & 858.5 & 403.4 & 20 & 100.8 & 176.5 & 1.225 \\
\hline C35P30 & 0.35 & 853.0 & 851.9 & 352.9 & 30 & 153.3 & 176.5 & 1.575 \\
\hline C40P0 & 0.40 & 901.0 & 899.5 & 441.2 & 0 & 0 & 176.5 & 1 \\
\hline C40P10 & 0.40 & 895.0 & 894.9 & 397.1 & 10 & 44.1 & 176.5 & 1.05 \\
\hline C40P20 & 0.40 & 890.0 & 888.2 & 352.9 & 20 & 88.2 & 176.5 & 1.2 \\
\hline C40P30 & 0.40 & 884.0 & 882.1 & 308.8 & 30 & 132.4 & 176.5 & 1.4 \\
\hline
\end{tabular}

* OPC + POFA, measured in weight $(\mathrm{kg}){ }^{\dagger}{ }^{+}$Involved in cement hydration.

\subsection{Preparation and Testing of Fresh Sustainable SCHSCs}

Coarse and fine aggregates were charged into the revolving pan-type concrete mixer and mixed with one-third of the mix water for $60 \mathrm{~s}$ to wet the aggregates sufficiently. Then, the mixer was stopped, 
the binder (OPC alone or with POFA) was added to the wet aggregates, and the mixing process was continued for $120 \mathrm{~s}$ with the second one-third of the mix water. Thereafter, the mixer was stopped, the pan was covered with a piece of wet burlap, and a resting period of $180 \mathrm{~s}$ was allowed for all of the concrete mixes. At the end of the resting period, the remaining one-third of the mix water blended with the HRWR dosage was added, and the mixing was continued for $180 \mathrm{~s}$ to produce the SCHSC mixes.

The filling ability of the SCHSC mixes was measured with respect to slump flow (SF), and the process was carried out according to the test method given in ASTM C1611/C1611M-14 [26]. The passing ability of the SCHSC mixes was measured with respect to J-ring flow (JF), following the test method depicted in the EFNARC specifications and guidelines [27]. The segregation resistance of the SCHSC mixes was measured with respect to sieve segregation, and the test was conducted according to the procedure given in Safiuddin et al. [28].

\subsection{Preparation and Testing of Hardened Sustainable SCHSCs}

Immediately after testing the fresh SCHSCs, the required $\varnothing 100 \times 200 \mathrm{~mm}$ cylinders were cast without any means of compaction. The specimens were de-moulded at the age of one day and immersed in cold water $\left(20^{\circ} \mathrm{C}\right)$ for curing until the day of testing. Most of these specimens were used to determine the compressive strength and UPV. Several $\varnothing 100 \times 200 \mathrm{~mm}$ cylinder specimens were cut to prepare $\varnothing 100 \times 50 \mathrm{~mm}$ cylinders required for testing the water absorption and permeable porosity of concrete. Three $\varnothing 100 \times 50 \mathrm{~mm}$ cylinder specimens were obtained from each $\varnothing 100 \times 200 \mathrm{~mm}$ cylinder. Triplicate specimens were used at each testing age for each property.

The compressive strength, UPV, water absorption, and permeable porosity were determined at the ages of 28 days and 56 days. The compressive strength test was performed in accordance with ASTM C39/C39M-17 [29]. The UPV of various SCHSC was determined following ASTM C597-16 [30]. A PUNDIT plus was used for determining UPV. The water absorption and permeable porosity tests were carried out according to the test procedures described in ASTM C642-13 [31].

\section{Test Results of Sustainable SCHSCs and Discussion}

\subsection{Workability}

The workability properties such as filling ability, passing ability, and segregation resistance were measured with respect to slump flow, J-ring flow, and sieve segregation, respectively. The results are shown in Table 4. The concretes at different $\mathrm{W} / \mathrm{B}$ ratios met the filling ability requirement of SCC with respect to slump flow. The slump flow of SCC must be in the range of $550 \mathrm{~mm}$ to $850 \mathrm{~mm}$ [27,32]. In this study, the slump flow of the freshly mixed concretes differed in the range of $605 \mathrm{~mm}$ to $720 \mathrm{~mm}$.

The J-ring flow was measured to determine the passing ability of concrete. The J-ring flow for different concrete mixes ranged from $570 \mathrm{~mm}$ to $700 \mathrm{~mm}$, which was $20-40 \mathrm{~mm}$ lower than the slump flow, as evident from Table 4 . The difference between slump flow and J-ring flow should be $\leq 50 \mathrm{~mm}$ for an SCC to ensure good passing ability without significant blockage [33]. From Table 4, it is obvious that all of the SCHSCs fulfilled the passing ability requirement of SCC.

The segregation indices varied in the range of $9-18.9 \%$, as shown in Table 4. According to Parez et al. [34], the recommended maximum limit for the segregation index is $18 \%$. Hence, all of the SCHSC mixes except $\mathrm{C} 25 \mathrm{P} 30$ had a reasonably good segregation resistance. It was also observed that an SCHSC mix with a greater slump flow provided a higher segregation index (as obvious from Table 4). The increased slump flow implied that the spread of concrete on the sieve was greater. Therefore, more mortar passed the sieve, leading to an increased segregation index (reduced segregation resistance). This is why C25P30 showed a lower segregation resistance, providing a segregation index of $18.9 \%$. Nevertheless, the detailed discussion on the filling ability, passing ability, and segregation resistance of different SCHSCs is beyond the scope of the present study, which has given more emphasis to determine the durability indicators for sustainable SCHSC. 
Table 4. Different workability properties of various sustainable SCHSCs.

\begin{tabular}{cccc}
\hline Concrete Mix & Slump Flow $(\mathbf{m m})$ & J-Ring Flow $(\mathbf{m m})$ & Segregation Index (\%) \\
\hline C25P0 & 660 & 620 & 11.1 \\
C25P10 & 680 & 645 & 13.9 \\
C25P20 & 705 & 680 & 17.9 \\
C25P30 & 720 & 700 & 18.9 \\
C30P0 & 640 & 605 & 10.3 \\
C30P10 & 655 & 625 & 10.9 \\
C30P20 & 670 & 645 & 13.6 \\
C30P30 & 700 & 675 & 17.0 \\
C35P0 & 630 & 590 & 10.4 \\
C35P10 & 640 & 610 & 10.0 \\
C35P20 & 665 & 630 & 11.2 \\
C35P30 & 675 & 650 & 12.0 \\
C40P0 & 605 & 570 & 9.0 \\
C40P10 & 620 & 595 & 9.3 \\
C40P20 & 630 & 600 & 10.1 \\
C40P30 & 645 & 615 & 10.4 \\
\hline
\end{tabular}

\subsection{Compressive Strength}

The compressive strength test was conducted at the ages of 28 days and 56 days. The average compressive strengths of the SCHSCs at different ages are presented in Table 5. In this study, the 28 days' compressive strength ranged from $52.3 \mathrm{MPa}$ to $74.2 \mathrm{MPa}$, while the 56 days' compressive strength ranged from $54.8 \mathrm{MPa}$ to $72.9 \mathrm{MPa}$ for different concretes. According to ACI Committee 363-10 [35], the strength range satisfied the minimum requirement (50 MPa) for high-strength concrete. In general, it was possible because the optimum FA/TA ratio, the use of relatively low $\mathrm{W} / \mathrm{B}$ ratio, and the incorporation of POFA densified the concrete with minimum voids.

Table 5. Compressive strength of various sustainable SCHSCs.

\begin{tabular}{ccccc}
\hline \multirow{2}{*}{ Concrete Mix } & W/B Ratio & \% POFA & \multicolumn{2}{c}{ Compressive Strength (MPa) } \\
\cline { 3 - 5 } & & & 28 Days & 56 Days \\
\hline C25P0 & 0.25 & 0 & 70.9 & 72.9 \\
C25P10 & 0.25 & 10 & 72.9 & 75.5 \\
C25P20 & 0.25 & 20 & 74.2 & 77.0 \\
C25P30 & 0.25 & 30 & 65.9 & 68.4 \\
C30P0 & 0.30 & 0 & 67.6 & 69.5 \\
C30P10 & 0.30 & 10 & 69.3 & 72.1 \\
C30P20 & 0.30 & 20 & 71.3 & 74.1 \\
C30P30 & 0.30 & 30 & 63.1 & 65.6 \\
C35P0 & 0.35 & 0 & 61.4 & 63.2 \\
C35P10 & 0.35 & 10 & 62.8 & 65.5 \\
C35P20 & 0.35 & 20 & 64.2 & 66.9 \\
C35P30 & 0.35 & 30 & 57.7 & 60.3 \\
C40P0 & 0.40 & 0 & 56.2 & 58 \\
C40P10 & 0.40 & 10 & 57.9 & 60.2 \\
C40P20 & 0.40 & 20 & 58.2 & 60.8 \\
C40P30 & 0.40 & 30 & 52.3 & 54.8 \\
\hline
\end{tabular}

The compressive strength of the SCHSCs increased with the decreased W/B ratio, as can be seen from Figure 2. As the water content was kept constant, the binder i.e., cement content increased at a lower W/B ratio (as evident from Table 3). At the higher cement content, the greater amount of calcium silicate hydrate (C-S-H) gel was produced, which improved the physical packing of aggregates, resulting in higher compressive strength. 


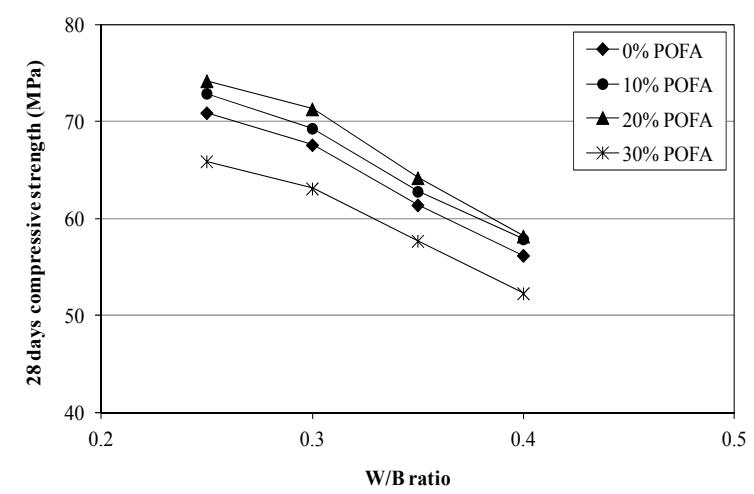

(a) 28 days

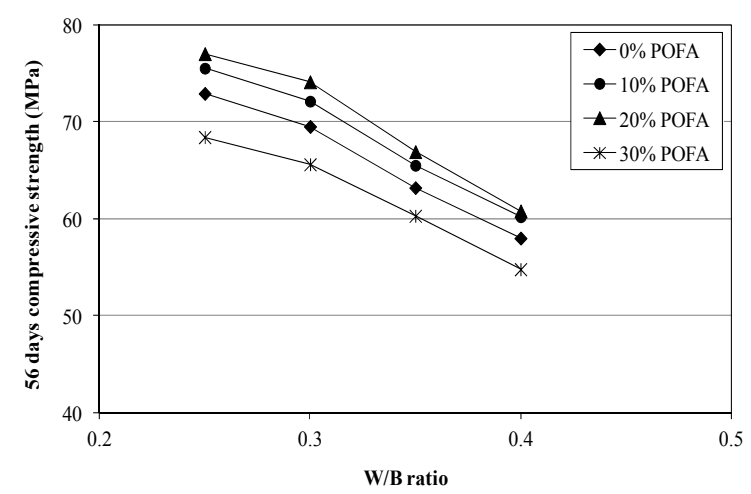

(b) 56 days

Figure 2. Effects of W/B ratio and POFA content on the compressive strength of sustainable SCHSCs.

The incorporation of POFA influenced the compressive strength of SCHSC. The compressive strength of concrete increased for $10 \%$ and $20 \%$ POFA, as obvious from Figure 2. Sata et al. [36] noticed a similar effect in their study. POFA was finer than cement, as noticed from the results of the sieve, Blaine, and BET fineness tests (refer to Table 1). Hence, POFA had the ability to fill in the microvoids in cement paste (physical effect). The micro-filling ability of POFA produced a dense concrete with reduced voids by blocking or narrowing the pore channels. In addition, the pozzolanic reaction of POFA contributed to increase the compressive strength of concrete at the later ages (28 to 56 days) by improving the microstructure/pore structure of bulk binder paste and strengthening the interfacial zone between binder paste and aggregate. The maximum compressive strength was achieved for 20\% POFA, as shown in Figure 2. It suggests that the $\mathrm{SiO}_{2}$ content present in $20 \%$ POFA was just enough to consume the entire amount of $\mathrm{Ca}(\mathrm{OH})_{2}$ liberated from cement hydration. Thus, it maximized the amount of additional or secondary C-S-H produced from the pozzolanic reaction of POFA (chemical effect). This is why the replacement of up to $20 \%$ of the OPC by POFA was possible without affecting the compressive strength of SCHSC, which indicated that $20 \%$ POFA optimized the gain in compressive strength. In contrast, 30\% POFA resulted in a reduction in the compressive strength of SCHSC. This is because the amount of $\mathrm{Ca}(\mathrm{OH})_{2}$ was relatively small due to $30 \%$ lower cement content. Therefore, the secondary C-S-H resulting from the pozzolanic reaction of POFA was not adequate to provide a higher compressive strength. This trend was observed at both 28 days and 56 days; the same trend is also expected for the ages later than 56 days.

\subsection{Ultrasonic Pulse Velocity (UPV)}

The UPV results of the SCHSCs at 28 days and 56 days are presented in Table 6. The UPV varied in the range of $4.55-4.85 \mathrm{~km} / \mathrm{s}$; thus, the concretes produced in this research can be categorized as "excellent concrete". This is because the concretes possessing a UPV higher than $4.5 \mathrm{~km} / \mathrm{s}$ generally expressed excellent quality [37]. The quality of SCHSCs was excellent, which was mostly due to the improvement in the pore structure of concrete resulting from the optimal FA/TA ratio, the lower W/B ratio, and the micro-filling ability and pozzolanic activity of POFA. Similar results were obtained by Lin et al. [38].

The UPV of the SCHSC increased with a lower W/B ratio, as evident from Figure 3 . The concretes produced with a W/B ratio of 0.25 provided the highest level of UPV. On the contrary, the concretes produced with a W/B ratio of 0.40 provided the lowest level of UPV. However, the UPV obtained for this $\mathrm{W} / \mathrm{B}$ ratio still represents the excellent physical quality of concrete. This is possibly because the aggregate content was increased at a higher $\mathrm{W} / \mathrm{B}$ ratio, as shown in Table 3 . The higher aggregate content accelerates the propagation of the ultrasonic pulse through concrete; therefore, the UPV is increased for the same strength level $[39,40]$. 
Table 6. Ultrasonic pulse velocity (UPV), permeable porosity, and water absorption of various sustainable SCHSCs.

\begin{tabular}{ccccccccc}
\hline \multirow{2}{*}{ Concrete Mix } & \multirow{2}{*}{ W/B Ratio } & \multirow{2}{*}{ \% POFA } & \multicolumn{2}{c}{ UPV $\mathbf{( k m / s )}$} & \multicolumn{2}{c}{ Permeable Porosity (\%) } & \multicolumn{2}{c}{ Water Absorption (\%) } \\
\cline { 4 - 8 } & & & 28 Days & 56 Days & 28 Days & 56 Days & 28 Days & 56 Days \\
\hline C25P0 & 0.25 & 0 & 4.74 & 4.76 & 7.98 & 7.58 & 3.46 & 3.30 \\
C25P10 & 0.25 & 10 & 4.76 & 4.79 & 7.51 & 7.18 & 3.26 & 3.10 \\
C25P20 & 0.25 & 20 & 4.80 & 4.85 & 7.04 & 6.88 & 3.00 & 2.97 \\
C25P30 & 0.25 & 30 & 4.72 & 4.75 & 8.10 & 7.71 & 3.54 & 3.36 \\
C30P0 & 0.30 & 0 & 4.70 & 4.72 & 8.95 & 8.60 & 3.91 & 3.77 \\
C30P10 & 0.30 & 10 & 4.72 & 4.75 & 8.59 & 8.30 & 3.74 & 3.61 \\
C30P20 & 0.30 & 20 & 4.75 & 4.8 & 8.21 & 8.10 & 3.53 & 3.52 \\
C30P30 & 0.30 & 30 & 4.68 & 4.71 & 9.12 & 8.71 & 3.97 & 3.81 \\
C35P0 & 0.35 & 0 & 4.64 & 4.67 & 9.99 & 9.85 & 4.41 & 4.29 \\
C35P10 & 0.35 & 10 & 4.66 & 4.71 & 9.70 & 9.42 & 4.22 & 4.10 \\
C35P20 & 0.35 & 20 & 4.68 & 4.76 & 9.43 & 8.93 & 3.99 & 3.86 \\
C35P30 & 0.35 & 30 & 4.6 & 4.63 & 10.25 & 10.13 & 4.51 & 4.41 \\
C40P0 & 0.40 & 0 & 4.57 & 4.60 & 11.16 & 10.96 & 4.89 & 4.81 \\
C40P10 & 0.40 & 10 & 4.60 & 4.64 & 10.92 & 10.59 & 4.76 & 4.62 \\
C40P20 & 0.40 & 20 & 4.63 & 4.68 & 10.59 & 10.39 & 4.59 & 4.44 \\
C40P30 & 0.40 & 30 & 4.55 & 4.58 & 11.50 & 11.25 & 5.03 & 4.92 \\
\hline
\end{tabular}

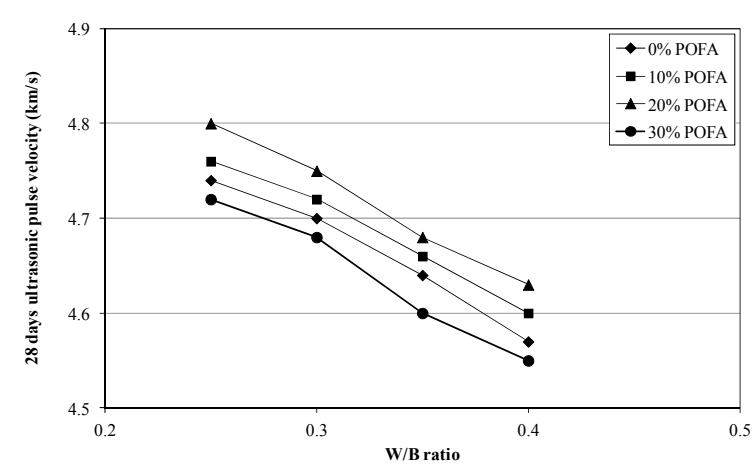

(a) 28 days

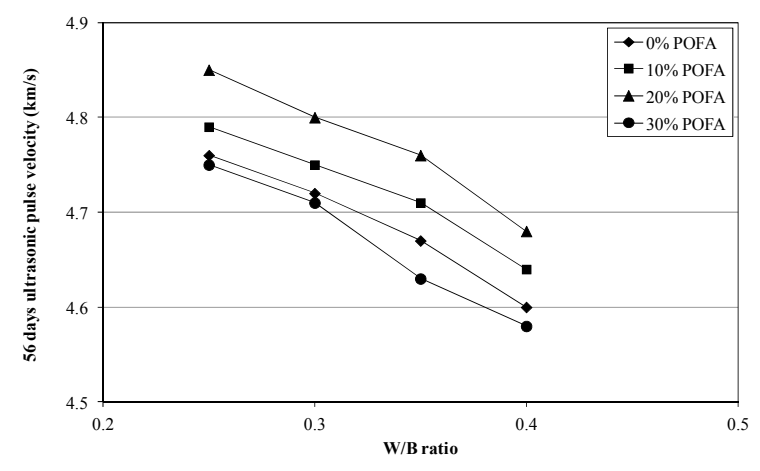

(b) 56 days

Figure 3. Effects of W/B ratio and POFA content on the UPV of sustainable SCHSCs.

POFA influenced the UPV of SCHSC, as evident from Figure 3. The presence of POFA was effective in improving the UPV of the concretes. The maximum UPV was obtained for the concrete including 20\% POFA content, which was due to the pore refinement of SCHSC with POFA leading to a dense microstructure that contributed to enhancing the UPV through concrete. However, a decrease in UPV was observed for 30\% POFA, because the pore refinement was not effective due to the reduced amount of secondary C-S-H. Also, a reduction in UPV may be attributed to a greater porosity of concrete. Indeed, the SCHSC with 30\% POFA had a greater permeable porosity, as obtained from the porosity test conducted in the present study.

\subsection{Permeable Porosity}

The boiling water method was used to determine the permeable porosity of SCHSCs. The average 28-day and 56-day permeable porosity results are shown in Table 6. The 28-day and 56-day permeable porosity values varied in the range of $7.04 \%$ to $11.50 \%$ and $6.88 \%$ to $11.25 \%$, respectively. The lowest level of permeable porosity was obtained for the concrete with a W/B ratio of 0.25 and $20 \%$ POFA content, whereas the highest level of permeable porosity was attained for the concrete with a W/B ratio of 0.40 and $30 \%$ POFA. The overall test results of permeable porosity indicate that the quality of the SCHSCs was good. According to Hearn et al. [41], the permeable porosity of high-quality concrete (high-strength concrete or high-performance concrete) is 7\%, whereas that of normal-quality concrete (regular or conventional concrete) is $15 \%$. 
The permeable porosity of the SCHSCs decreased with a lower W/B ratio, as can be seen from Figure 4 . This is because the cement content increased at a lower $\mathrm{W} / \mathrm{B}$ ratio, which produced a greater amount of hydration products, such as calcium silicate hydrate (C-S-H) and calcium aluminate hydrate (C-A-H). These hydration products refined the pore structure of concrete by filling up more of the microvoids that were present in the bulk cement paste and transition zone of concrete. Consequently, the microstructure of concrete was improved with reduced permeable porosity. A similar effect of the $\mathrm{W} / \mathrm{B}$ ratio on the permeable porosity was observed by the other researchers in the case of normal and high-strength concretes [7,42].

The permeable porosity of SCHSC decreased with an increase in POFA content up to $20 \%$, as can be seen from Figure 4 . The pozzolanic activity and micro-filling ability of POFA were effective for the SCHSCs with $10 \%$ and $20 \%$ POFA contents. The higher $\mathrm{SiO}_{2}$ content $(62.3 \%)$ and the higher fineness of ground POFA allowed it to react with the calcium hydroxide $\left[\mathrm{Ca}(\mathrm{OH})_{2}\right]$ that was liberated from cement hydration to produce secondary C-S-H, which filled the microvoids in the bulk cement paste and transition zone. The amount of POFA available at 20\% POFA content was probably utilized completely to produce the maximum amount of secondary C-S-H by consuming the entire $\mathrm{Ca}(\mathrm{OH})_{2}$. Hence, the minimum permeable porosity was achieved at 20\% POFA content.

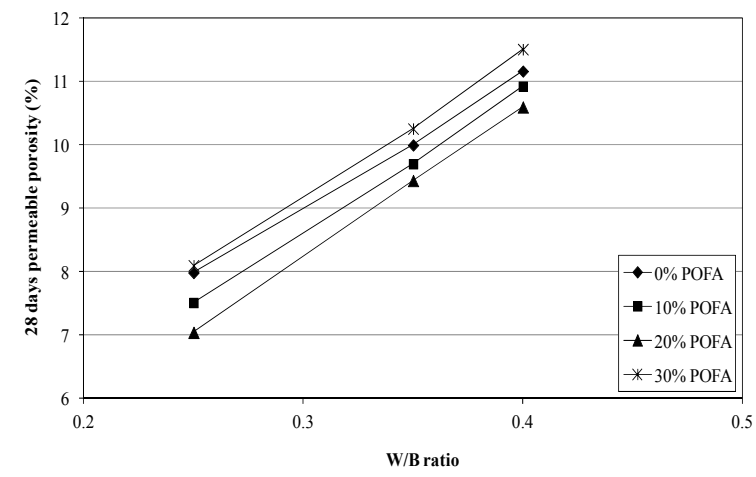

(a) 28 days

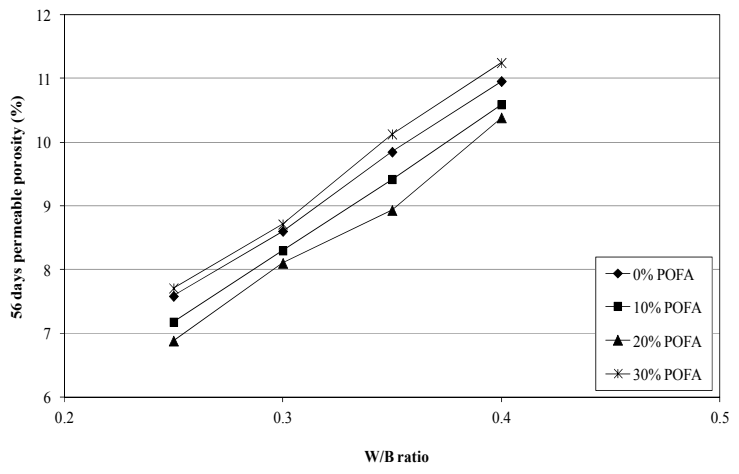

(b) 56 days

Figure 4. Effects of W/B ratio and POFA content on the permeable porosity of sustainable SCHSCs.

The permeable porosity of the concretes increased in the presence of $30 \%$ POFA content, as evident from Figure 4. This is mainly due to the reduced hydration products obtained from a lower cement content. The increased POFA content decreased the amount of OPC in concrete. The reduction in cement content was more at 30\% POFA content, as evident from Table 3; this resulted in a relatively low amount of primary C-S-H. Furthermore, the amount of $\mathrm{Ca}(\mathrm{OH})_{2}$ generated from cement hydration was decreased at the reduced amount of cement. Hence, all POFA particles at 30\% POFA content perhaps could not react with $\mathrm{Ca}(\mathrm{OH})_{2}$ to maximize the production of secondary C-S-H from the pozzolanic reaction. Consequently, the SCHSC with 30\% POFA possessed a greater permeable porosity than the control concrete.

\subsection{Water Absorption}

The water absorption of all SCHSCs was determined using the boiling water method. The average test results for the 28-day and 56-day water absorption of different SCHSCs are presented in Table 6. The 28-day and 56-day water absorption values varied in the range of 3.0 to $5.03 \%$ and 2.97 to $4.92 \%$, respectively. These results suggest that the water absorption of SCHSC was relatively low. The low water absorption values indicate that the concrete quality was high. The water absorption of high-quality concrete (high-strength concrete or high-performance concrete) is generally less than $5 \%$ [43]. The low range of water absorption was obtained in the present study due to the reduced permeable porosity and limited pore connectivity in the concretes [9]. 
The water absorption of SCHSC increased with a higher W/B ratio, as obvious from Figure 5. In the present study, the highest level of water absorption was noticed for the concrete prepared with the $\mathrm{W} / \mathrm{B}$ ratio of 0.40 . On the contrary, the lowest level of water absorption was achieved for the concrete produced with the $\mathrm{W} / \mathrm{B}$ ratio of 0.25 . This is for the same reasons as discussed in the case of the permeable porosity of SCHSC. Moreover, the water absorption is directly related to the permeable porosity of concrete. It decreases with lower permeable porosity. The lower degree of pore connectivity due to greater hydration products from a higher cement content also contributed to decrease the water absorption of SCHSC.

The effect of POFA on the water absorption was similar to that of the permeable porosity of SCHSC. The lowest level of water absorption was produced by $20 \%$ POFA content. In the presence of $20 \%$ POFA, the 28-day and 56-day water absorption of concrete was reduced by about $14 \%$ and $16 \%$, respectively, compared with the control concretes. This reduction in water absorption is primarily credited to the reduced permeable porosity of concrete at $20 \%$ POFA content. The reduced pore connectivity due to the micro-filling ability and pozzolanic activity of POFA also contributed to lessen the water absorption of SCHSC. However, Figure 5 shows that the water absorption of the SCHSC with $30 \%$ POFA slightly increased compared with the control concrete. This is because the permeable porosity of concrete increased for 30\% POFA content, as discussed earlier in Section 3.3.

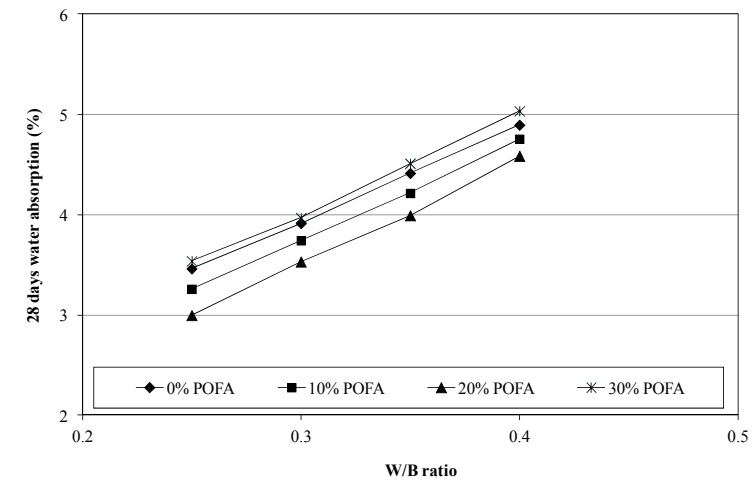

(a) 28 days

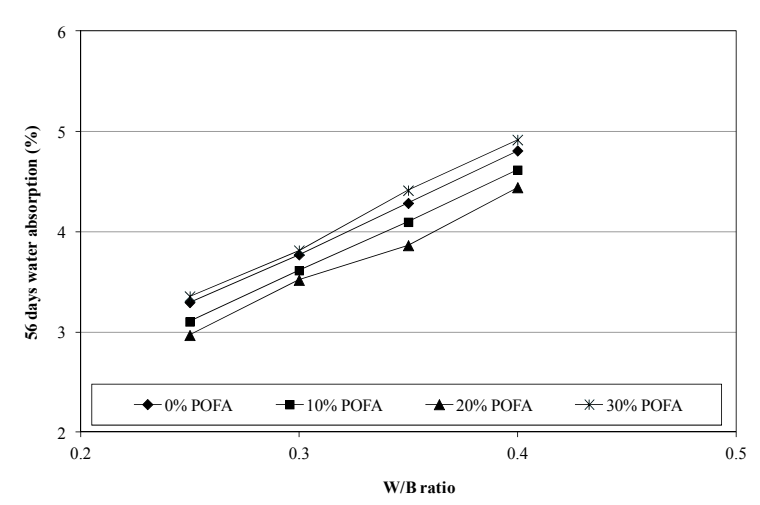

(b) 56 days

Figure 5. Effects of W/B ratio and POFA content on the water absorption of sustainable SCHSCs.

\subsection{Correlation between Compressive Strength and UPV of Sustainable SCHSCS}

The correlation between the compressive strength and UPV of SCHSC is shown in Figure 6. The correlation equation is $\mathrm{f}_{\mathrm{c}}{ }^{\prime}=85.723\left(\mathrm{~V}_{\mathrm{up}}\right)-337.33$, where $\mathrm{V}_{\text {up }}$ and $\mathrm{f}_{\mathrm{c}}{ }^{\prime}$ are the $\mathrm{UPV}$ and compressive strength of concrete, respectively. This equation is valid for the UPV varying from $4.55 \mathrm{~km} / \mathrm{s}$ to $4.85 \mathrm{~km} / \mathrm{s}$, and the compressive strength ranging from 52.3 MPa to 77.0 MPa. In the present study, they varied with the $\mathrm{W} / \mathrm{B}$ ratio and POFA content of concrete i.e., the compressive strength and UPV increased with a lower W/B ratio and higher POFA content (up to 20\%). Therefore, a strong positive linear relationship with a correlation coefficient $(r)$ of +0.9709 was observed for the compressive strength and UPV of SCHSC, as evident from Figure 6. Demirboğa et al. [44] also observed a strong correlation between compressive strength and ultrasonic pulse velocity for the concretes including fly ash and slag, and Safiuddin [7] observed a similar correlation for the concretes incorporating rice husk ash. 


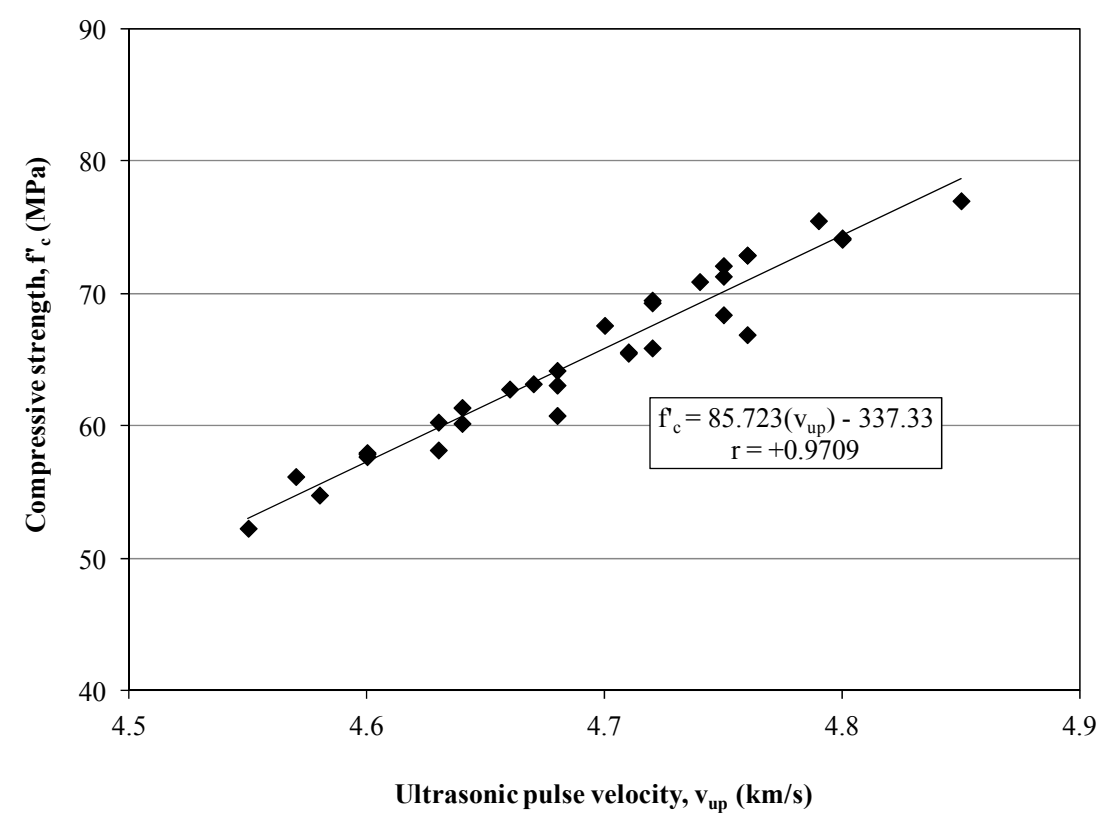

Figure 6. Correlation between the compressive strength and UPV of sustainable SCHSCs.

\subsection{Correlation between Permeable Porosity and UPV of Sustainable SCHSCs}

The correlation between the UPV and permeable porosity of SCHSC is shown in Figure 7. The correlation equation is $\mathrm{p}=-17.127\left(\mathrm{~V}_{\mathrm{up}}\right)+89.568$, where $\mathrm{p}$ and $\mathrm{V}_{\mathrm{up}}$ are the permeable porosity and UPV of concrete, respectively. This equation is valid when the permeable porosity varies from $6.88 \%$ to $11.50 \%$ and the UPV differs in the range of $4.55-4.85 \mathrm{~km} / \mathrm{s}$.

Figure 7 reveals that the UPV and permeable porosity of SCHSC are strongly correlated with a negative linear relationship, which has the correlation coefficient of 0.9524 . Such a strong negative relationship was noticed, as the UPV and permeable porosity had an inverse relationship to the W/B ratio and POFA content: the porosity increased, whereas the UPV decreased with a higher $\mathrm{W} / \mathrm{B}$ ratio and lower POFA content. A similar relationship was observed for the concretes, including rice husk ash [7].

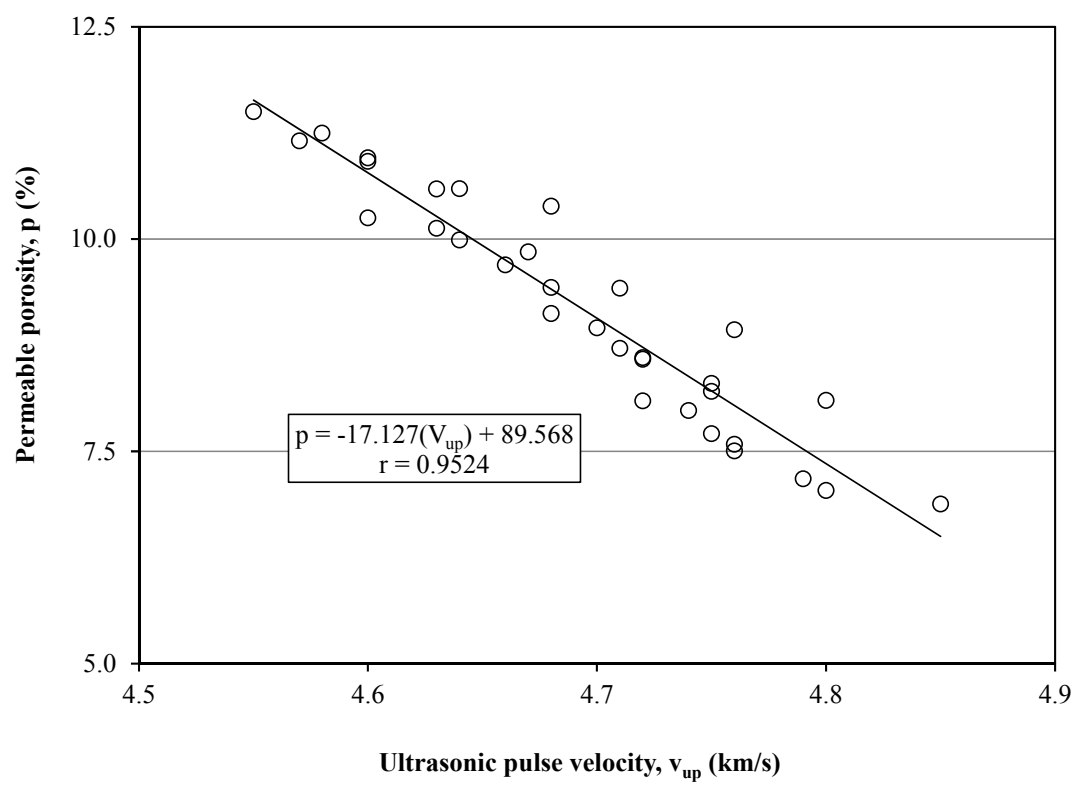

Figure 7. Correlation between the permeable porosity and UPV of sustainable SCHSCs. 


\subsection{Correlation between UPV and Water Absorption of Sustainable SCHSCs}

The correlation between the UPV and water absorption of SCHSC is shown in Figure 8. The correlation equation is $W_{a}=-7.667\left(V_{u p}\right)+39.978$, where $W_{a}$ and $V_{u p}$ are the water absorption and UPV of concrete, respectively. This equation is valid when the water absorption varies from $2.97 \%$ to $5.03 \%$ and the UPV varies from $4.55 \mathrm{~km} / \mathrm{s}$ to $4.85 \mathrm{~km} / \mathrm{s}$.

Figure 8 reveals that a negative linear relationship between the water absorption and UPV of SCHSC was observed, similar to its permeable porosity versus UPV relationship. Such a negative linear relationship was observed, since the UPV increased whereas the water absorption decreased with a lower W/B ratio and higher POFA content. Moreover, the correlation coefficient was 0.9585, which suggests a strong relationship. Hence, the water absorption and UPV of SCHSC are strongly correlated.

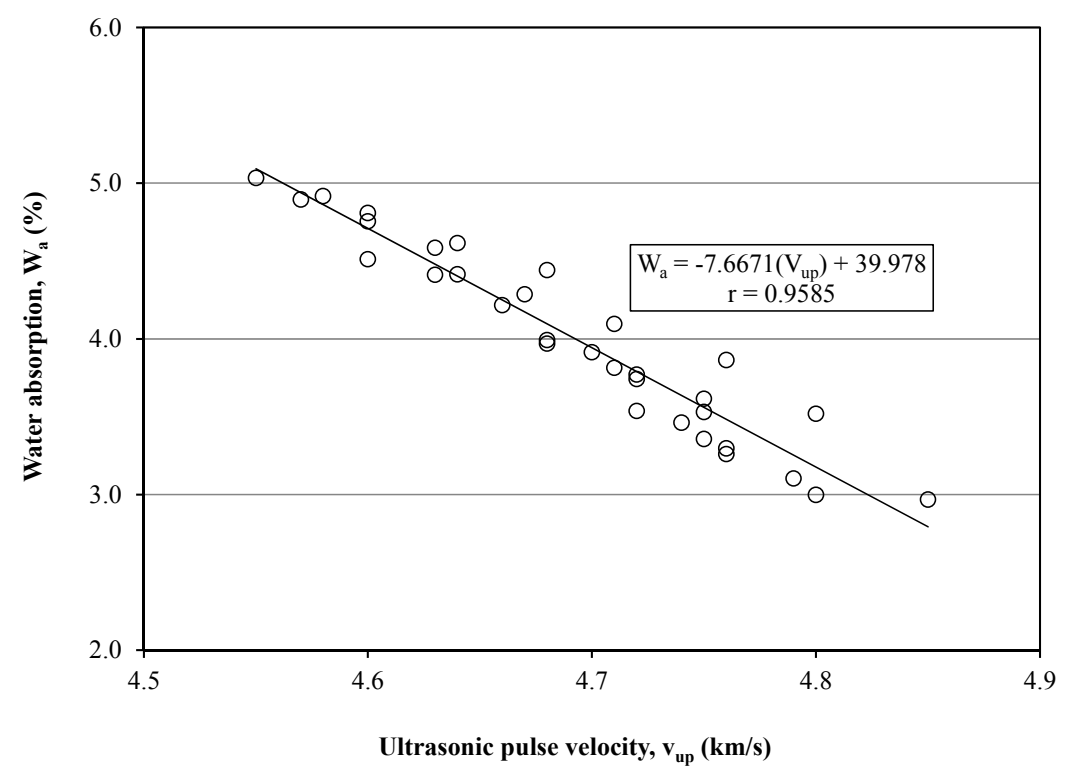

Figure 8. Correlation between the water absorption and UPV of sustainable SCHSCs.

\section{Cost and Sustainability of POFA Incorporated SCHSCs}

The approximate prices of the different constituent materials that were used in the SCHSC mixes are shown in Table 7 . In addition, Table 8 shows the cost comparison of the different control (0\% POFA) and optimum SCHSC mixes (20\% POFA) prepared with various W/B ratios.

Table 7. Prices of the different constituent materials used in SCHSCs.

\begin{tabular}{ccc}
\hline \multirow{2}{*}{ Material } & \multicolumn{2}{c}{ Price } \\
\cline { 2 - 3 } & $\mathbf{R M} * \mathbf{k g}$ & USD ${ }^{* * / \mathbf{k g}}$ \\
\hline OPC & 0.280 & 0.070 \\
Crushed granite stone & 0.060 & 0.015 \\
Mining sand & 0.060 & 0.015 \\
Fly ash & 0.150 & 0.038 \\
Slag & 0.200 & 0.050 \\
Limestone powder & 0.250 & 0.063 \\
POFA & 0.020 & 0.005 \\
Metakaolin & 3.00 & 0.750 \\
Silica fume & 4.00 & 1.000 \\
HRWR & 12.000 & 3.000 \\
Water & 0.0025 & 0.0006
\end{tabular}

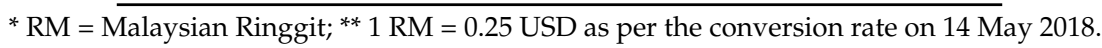


Table 7 shows that POFA is substantially cheaper than OPC, as well as many well-known mineral admixtures such as fly ash, metakaolin, silica fume, slag, and limestone powder, which are commonly used to produce HSC. The total costs of the selected SCHSC mixes given in Table 8 indicate that some cost savings could be achieved if POFA is used to produce SCHSC. For the SCHSC mixes shown in Table 8, the reduction in concrete cost was 3-9.2\%. Hence, from the environmental and economic viewpoints, the POFA-incorporated SCHSCs shall be sustainable due to the cost savings and the utilization of waste in concrete.

Table 8. Material cost comparison of different control and optimum SCHSC mixes.

\begin{tabular}{ccccccccc}
\hline \multirow{2}{*}{ Constituent Material } & \multicolumn{7}{c}{ Material Cost of SCHSC $\left(\mathbf{U S D} / \mathbf{m}^{\mathbf{3}}\right.$ ) } \\
\cline { 2 - 9 } & C25P0 & C25P20 & C30P0 & C30P20 & C35P0 & C35P20 & C40P0 & C40P20 \\
\hline CA & 11.7 & 11.4 & 12.5 & 12.3 & 13.1 & 12.9 & 13.5 & 13.3 \\
FA & 11.7 & 11.4 & 12.5 & 12.3 & 13.1 & 12.9 & 13.5 & 13.3 \\
OPC & 49.4 & 39.5 & 41.2 & 32.9 & 35.3 & 28.2 & 30.9 & 24.7 \\
POFA & - & 0.7 & - & 0.6 & - & 0.5 & - & 0.4 \\
Water & 0.1 & 0.1 & 0.1 & 0.1 & 0.1 & 0.1 & 0.1 & 0.1 \\
HRWR & 38.1 & 42.4 & 26.5 & 31.8 & 18.9 & 18.5 & 13.2 & 15.9 \\
Total cost & 111.0 & 105.5 & 92.8 & 90.0 & 80.5 & 73.1 & 71.2 & 67.7 \\
Cost savings & - & $5 \%$ & - & $3 \%$ & - & $9.2 \%$ & - & $4.9 \%$ \\
\hline
\end{tabular}

\section{Durability Indicators for Sustainable SCHSCs}

The strong correlations of compressive strength, permeable porosity, and water absorption with UPV were used to determine the durability indicators for SCHSC. Three ranges of UPV values were fixed for the three different quality levels ('excellent', 'very good', and 'good') of SCHSC based on the well-established UPV values that are available in literature [45]. The decided UPV values were used to set the compressive strength, permeable porosity, and water absorption values as the durability indicators for the different levels of durability for SCHSC (refer to Table 9). It is well known that permeable porosity mainly affects the durability properties (water absorption, water/gas permeability, chloride diffusion/penetration, etc.) of concrete. Through the permeable pores, water carries many deleterious agents (chlorides, sulfates, etc.) that affect the durability performance (resistance to corrosion, resistance to sulfate attack, etc.) of concrete. Water is also directly involved with the corrosion of steel reinforcement, freeze-thaw damage, and alkali-aggregate reactions in concrete. Moreover, many damage mechanisms, such as freeze-thaw cracking, abrasion, corrosion cracking, etc., are related to the strength of concrete. Therefore, permeable porosity, water absorption, and compressive strength have been selected to be used as the durability indicators. Based on the present study, Table 9 suggests that an SCHSC with a compressive strength of $>50 \mathrm{MPa}$, a permeable porosity of $<12 \%$, and a water absorption of $<6.0 \%$ would possess high durability.

Table 9. Durability indicators for the different durability levels of sustainable SCHSCs.

\begin{tabular}{cccccc}
\hline \multirow{2}{*}{$\begin{array}{c}\text { Concrete } \\
\text { Quality }\end{array}$} & UPV (km/s) & $\begin{array}{c}\text { Compressive } \\
\text { Strength (MPa) }\end{array}$ & $\begin{array}{c}\text { Permeable } \\
\text { Porosity (\%) }\end{array}$ & $\begin{array}{c}\text { Water Absorption } \\
\mathbf{( \% )}\end{array}$ & $\begin{array}{c}\text { Durability } \\
\text { Level }\end{array}$ \\
\hline Excellent & $>5.0$ & $>90$ & $<4$ & $<2$ & Outstanding \\
Very good & $4.75-5.0$ & $70-90$ & $4-8$ & $2-4$ & Very high \\
Good & $4.5-4.75$ & $50-70$ & $8-12$ & $4-6$ & High \\
\hline
\end{tabular}

\section{Conclusions}

The overall research findings of the present study regarding sustainable SCHSCs with POFA are concluded below. 
- The performance criteria for filling ability and passing ability were fulfilled for all of the SCHSCs incorporating $0-30 \%$ POFA. The performance criterion for segregation resistance was fulfilled for all of the SCHSCs except for C25P30 including 30\% POFA. Also, the minimum requirement for the compressive strength of HSC was fulfilled for all of the SCHSCs including 0-30\% POFA. However, 20\% POFA was most effective to provide high compressive strength as well as good filling ability and passing ability with adequate segregation resistance.

- The compressive strength and durability properties, such as the permeable porosity and water absorption of SCHSC were improved with a lower W/B ratio. The lower W/B ratio was associated with higher binder content, which produced greater hydration products. The enhanced paste densification due to these products resulted in a dense microstructure or a compact pore structure, leading to an increased compressive strength and improved durability properties.

- Excellent compressive strength and durability properties were achieved for the SCHSCs with $10 \%$ and $20 \%$ POFA contents. The fineness of POFA played an important role in enhancing the compressive strength and durability properties of hardened concrete. The high fineness of POFA improved its micro-filling ability and pozzolanic activity, and thus contributed to improving the aforementioned properties of concrete.

- POFA content higher than $20 \%$ was not effective in improving the compressive strength and durability properties of SCHSC. At 30\% POFA content, the amount of OPC was decreased; thus, a comparatively low amount of $\mathrm{Ca}(\mathrm{OH})_{2}$ was produced from cement hydration. Hence, the entire amount of silica $\left(\mathrm{SiO}_{2}\right)$ present in $30 \%$ POFA could not react with the liberated $\mathrm{Ca}(\mathrm{OH})_{2}$ to maximize the production of secondary C-S-H from pozzolanic reaction. Consequently, the compressive strength and durability properties were relatively low for the SCHSC including $30 \%$ POFA.

- The use of POFA in producing SCHSC will be cost-effective and environment-friendly compared with using cement alone; also, POFA will be more cost-effective than many of the other mineral admixtures that are commonly used in HSC.

- The compressive strength, permeable porosity, and water absorption of SCHSC were strongly correlated with its UPV. These strong relationships imply that an SCHSC with a compressive strength greater than $50 \mathrm{MPa}$, a permeable porosity less than $12 \%$, and a water absorption lower than $6 \%$ would provide high durability.

Author Contributions: Conceptualization, M.S.; Methodology, M.S. and M.A.S.; Experimental Investigation and Data Curation, M.A.S.; Supervision, M.S. and M.Z.J.; Project Administration, M.Z.J.; Formal Analysis, M.S. and M.A.S.; Writing_-Original Draft Preparation, M.A.S.; Writing—Review \& Editing, M.S. and M.Z.J.

Funding: This research was funded through the research grant, RG050-09AET, given by the University of Malaya, Kuala Lumpur, Malaysia.

Acknowledgments: The authors gratefully acknowledge the financial support from the University of Malaya, Kuala Lumpur, Malaysia. The authors are also thankful to Jugra Palm Oil Mill Sdn. Bhd., Banting, Selangor Darul Ehsan, Malaysia for supplying palm oil fuel ash for this research.

Conflicts of Interest: The authors declare no conflict of interest.

\section{References}

1. Khayat, K.H. Workability, testing, and performance of self-consolidating concrete. ACI Mater. J. 1990, 96, 346-353.

2. Okamura, H.; Ouchi, M. Self-compacting concrete. J. Adv. Concr. Technol. 2003, 1, 5-15. [CrossRef]

3. Okamura, H.; Ozawa, K. Mix design for self-compacting concrete. Concr. Libr. JSCE 1995, 25, 107-120.

4. Ozawa, K. Development of high performance concrete based on the durability design of concrete structures. In Proceedings of the 2nd East Asia Pacific Conference on Structural Engineering and Construction, Chiang-Mai, Thailand, 11-13 January 1989; pp. 445-450. 
5. Cyr, M.; Mouret, M. Rheological characterization of superplasticized cement pastes containing mineral admixtures: Consequences on self-compacting concrete design. In Proceedings of the Seventh CANMET / ACI International Conference on Superplasticizers and other Chemical Admixtures in Concrete, Berlin, Germany, 20-23 October 2003; pp. 241-256.

6. Kim, H.; Park, Y.-D.; Noh, J.; Song, Y.; Han, C.; Kang, S. Rheological properties of self-compacting, high-performance concrete. In Proceedings of the Third CANMET/ACI International Conference; Malhotra, V.M., Ed.; American Concrete Institute: Farmington Hills, MI, USA, 1997; pp. 653-668.

7. Safiuddin, M. Development of Self-Consolidating High Performance Concrete Incorporating Rice Husk Ash. Ph.D. Thesis, University of Waterloo, Waterloo, ON, Canada, 2008.

8. Safiuddin, Md.; Salam, M.A.; Jumaat, M.Z. Flowing ability of self-consolidating concrete and its binder paste phase including palm oil fuel ash. Mag. Concr. Res. 2012, 64, 931-944. [CrossRef]

9. Safiuddin, Md.; West, J.S.; Soudki, K.A. Hardened properties of self-consolidating high performance concrete including rice husk ash. Cem. Concr. Compos. 2010, 32, 708-717. [CrossRef]

10. Abdullah, K.; Hussin, M.W.; Zakaria, F.; Muhamad, R.; Hamid, Z.A. POFA: A potential partial cement replacement material in aerated concrete. In Proceedings of the 6th Asia-Pacific Structural Conference on Engineering and Construction (APSEC 2006), Kuala Lumpur, Malaysia, 5-6 September 2006; pp. B132-B140.

11. Tangchirapat, W.; Jaturapitakkul, C.; Chindaprasirt, P. Use of Palm Oil Fuel Ash as a Supplementary Cementitious Material for Producing High-Strength Concrete. Constr. Build. Mater. 2009, 23, 2641-2646. [CrossRef]

12. Tonnayopas, D.; Nilrat, F.; Putto, K.; Tantiwitayawanich, J. Effect of oil palm fiber fuel ash on compressive strength of hardening concrete. In Proceedings of the 4th Thailand Materials Science and Engineering, Pathumthani, Thailand, 31 March-1 April 2006; pp. 1-3.

13. Sumadi, S.R.; Hussin, M.W. Palm oil fuel ash (POFA) as a future partial cement replacement material in housing construction. J. Ferrocem. 1995, 25, 25-34.

14. Alsubari, B.; Shafigh, P.; Jumaat, M.Z. Development of self-consolidating high strength concrete incorporating treated palm oil fuel ash. Materials 2015, 8, 2154-2173. [CrossRef]

15. Safiuddin, Md.; Salam, M.A.; Jumaat, M.Z. Utilization of palm oil fuel ash in concrete: A review. J. Civ. Eng. Manag. 2011, 17, 234-247. [CrossRef]

16. Salam, M.A.; Safiuddin, Md.; Jumaat, M.Z. Non-destructive evaluation of self-consolidating high-strength concrete incorporating palm oil fuel ash. Br. J. Appl. Sci. Technol. 2015, 11, 1-13. [CrossRef]

17. Alsubari, B.; Shafigh, P.; Jumaat, M.Z.; Alengaram, U.J. Palm oil fuel ash as a partial cement replacement for producing durable self-consolidating high-strength concrete. Arabian J. Sci. Eng. 2014, 39, 8507-8516. [CrossRef]

18. Ofuyatan, T.; Olutoge, F.; Olowofoyeku, A. Durability properties of palm oil fuel ash self compacting concrete. Eng. Technol. Appl. Sci. Res. 2015, 5, 753-756.

19. Ranjbar, N.; Behnia, A.; Alsubari, B.; Birgani, P.M.; Jumaat, M.Z. Durability and mechanical properties of self-compacting concrete incorporating palm oil fuel ash. J. Clean. Prod. 2016, 112, 723-730. [CrossRef]

20. Standard Test Methods for Fineness of Hydraulic Cement by Air-Permeability Apparatus; ASTM C 204-04; ASTM International: West Conshohocken, PA, USA, 2004.

21. Standard Test Method for Advanced Ceramic Specific Surface Area by Physical Adsorption; ASTM C 1274-10; ASTM International: West Conshohocken, PA, USA, 2010.

22. Standard Specification for Use of Silica Fume as Mineral Admixture in Hydraulic Cement Concrete, Mortar and Grout; ASTM C 1240-04; ASTM International: West Conshohocken, PA, USA, 2004.

23. ACI. 211.4R-08: Guide for selecting proportions for high-strength concrete using Portland cement and other cementitious materials. In ACI Manual of Concrete Practice, Part 1; American Concrete Institute: Farmington Hills, MI, USA, 2008.

24. Sata, V.; Jaturapitakkul, C.; Kiattikomol, K. Utilization of palm oil fuel ash in high-strength concrete. J. Mater. Civ. Eng. 2004, 16, 623-628. [CrossRef]

25. Hussin, M.W.; Abdullah, K. Properties of palm oil fuel ash cement based aerated concrete panel subjected to different curing regimes. Malays. J. Civ. Eng. 2009, 21, 17-31.

26. Standard Test Method for Slump Flow of Self-Consolidating Concrete; ASTM C 1611/C 1611M-14; ASTM International: West Conshohocken, PA, USA, 2014. 
27. Specifications and Guidelines for Self-Consolidating Concrete; European Federation of Supplies of Specialist Construction Chemicals (EFNARC): Farnham, UK, 2002.

28. Safiuddin, Md.; West, J.S.; Soudki, K.A. Self-Consolidating High Performance Concrete with Rice Husk Ash: Components, Properties, and Mixture Design, 1st ed.; VDM Publishing House Ltd: Saabruecken, Germany, 2009.

29. Standard Test Method for Compressive Strength of Cylindrical Concrete Specimens; ASTM C 39/C 39M-17; ASTM International: West Conshohocken, PA, USA, 2017.

30. Standard Test Method for Pulse Velocity through Concrete; ASTM C 597; ASTM International: West Conshohocken, PA, USA, 2016.

31. Standard Test Method for Density, Absorption, and Voids in Hardened Concrete; ASTM C 642-13; ASTM International: West Conshohocken, PA, USA, 2013.

32. Khayat, K.H. Optimization and performance of air-entrained, self-consolidating concrete. ACI Mater. J. 2000, 97, 526-535.

33. Brameshuber, W.; Uebachs, S. Practical experience with the application of self-compacting concrete in Germany. In Proceedings of the Second International Symposium on Self-Compacting Concrete; Ozawa, K., Ouchi, M., Eds.; COMS Engineering Corporation: Tokyo, Japan, 2001; pp. 687-695.

34. Parez, N.; Romero, H.; Hermida, G.; Cuellar, G. Self-compacting concrete, on the search and finding of an optimized design. In Proceedings of the First North American Conference on the Design and Use of Self-Consolidating Concrete; Shah, S.P., Daczko, J.A., Lingscheit, J.N., Eds.; Hanley-Wood, LLC: Rosemont, IL, USA, 2002; pp. 101-107.

35. ACI 363R-10: Report on high-strength concrete. In ACI Manual of Concrete Practice; American Concrete Institute: Farmington Hills, MI, USA, 2010.

36. Sata, V.; Jaturapitakkul, C.; Rattanashotinunt, C. Compressive strength and heat evolution of concretes containing palm oil fuel ash. J. Mater. Civ. Eng. 2007, 22, 1033-1038. [CrossRef]

37. Neville, A.M. Properties of Concrete, 4th ed.; John Wiley \& Sons Inc.: New York, NY, USA, 1996.

38. Lin, Y.; Lai, C.-P.; Yen, T. Prediction of ultrasonic pulse velocity (UPV) in concrete. ACI Mater. J. 2003, 100, 21-28.

39. Naik, T.R.; Malhotra, V.M.; Popovics, J.S. The ultrasonic pulse velocity method. In Handbook on Nondestructive Testing of Concrete; CRC Press: Boca Raton, FL, USA, 2004; pp. 189-207.

40. Shetty, M. Concrete Technology: Theory and Practice; S. Chand and Company Ltd.: New Delhi, India, 2001.

41. Hearn, N.; Hooton, R.D.; Mills, R.H. Pore structure and permeability. In Significance of Tests and Properties of Concrete and Concrete-Making Materials; American Society for Testing and Materials: West Conshohocken, PA, USA, 1994; pp. 240-262.

42. Maeda, N.; Wada, I.; Kawakami, M.; Ueda, T.; Pushpalal, G.K.D. Chloride diffusivity of concrete incorporating rice husk ash. In Proceedings of the Fifth CANMET/ACI International Conferences on Recent Advances in Concrete Technology; Malhotra, V.M., Ed.; American Concrete Institute: Farmington Hills, MI, USA, 2001; pp. 291-308.

43. Kosmatka, S.H.; Kerkhoff, B.; Panarese, W.C.; MacLeod, N.F.; McGrath, R.J. Design and Control of Concrete Mixtures; Cement Association of Canada: Ottawa, ON, Canada, 2002.

44. Demirboğa, R.; Türkmen, İ.; Karakoc, M.B. Relationship between ultrasonic velocity and compressive strength for high-volume mineral-admixtured concrete. Cem. Concr. Res. 2004, 34, 2329-2336. [CrossRef]

45. Leslie, R., Jr.; Cheesman, W.J. An ultrasonic method of studying deterioration and cracking in concrete structures. ACI J. Proc. 1949, 46, 17-36.

(C) 2018 by the authors. Licensee MDPI, Basel, Switzerland. This article is an open access article distributed under the terms and conditions of the Creative Commons Attribution (CC BY) license (http:/ / creativecommons.org/licenses/by/4.0/). 